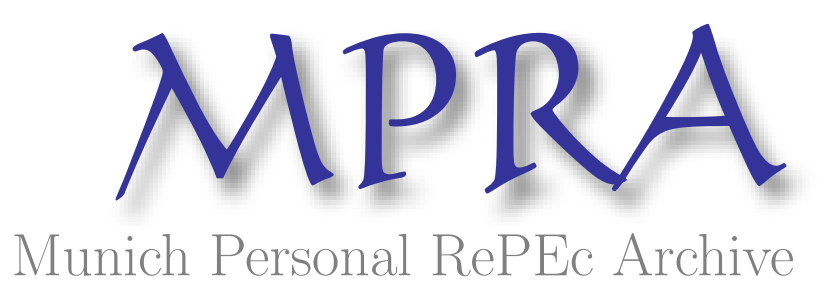

\title{
Is Market-Oriented Reform Producing a "Two-Track" Europe? Evidence from Electricity and Telecommunications
}

Judith Clifton and Daniel Díaz-Fuentes and Marcos Fernández Gutiérrez and Julio Revuelta

Universidad de Cantabria, Spain

2011

Online at http://mpra.ub.uni-muenchen.de/33018/

MPRA Paper No. 33018, posted 27. August 2011 14:44 UTC 


\title{
Is Market-Oriented Reform Producing a "Two-Track" Europe? Evidence from Electricity and Telecommunications
}

Judith Clifton, Daniel Díaz-Fuentes, Marcos Fernández-Gutiérrez and Julio Revuelta, Departamento de Economía, Universidad de Cantabria, Av. De los Castros S. N., Santander, Cantabria, 39005, Spain

\begin{abstract}
The European Commission has formally recognised that adequate provision of basic household services, including energy, communications, water and transport, is key to ensuring equity, social cohesion and solidarity. Yet little research has been done on the impact of the reform of these services in this regard. This article offers an innovative way to explore such questions by analysing and contrasting stated and revealed preferences on citizen satisfaction with and expenditure on two services, electricity and telecommunications, in two large countries, Spain and the United Kingdom. In telecommunications, but to a much lesser extent in electricity, we find evidence that reform has led to a "two-track" Europe, where citizens who are elderly, not working or the less-educated behave differently in the market, with the result that they are less satisfied with these services than their younger, working, better-educated, counterparts.
\end{abstract}

\section{¿Están generando las reformas orientadas hacia el mercado una Europa de "dos velocidades"? Evidencia para los casos de la electricidad y las telecomunicaciones}

Judith Clifton, Daniel Díaz-Fuentes, Marcos Fernández-Gutiérrez y Julio Revuelta, Departamento de Economía, Universidad de Cantabria, Av. De los Castros S. N., Santander, Cantabria, 39005, Spain

\section{Resumen}

La Comisión Europea ha establecido que la adecuada provisión de servicios básicos para los hogares, tales como la energía, las telecomunicaciones, el agua y el transporte, es clave para garantizar la equidad, la cohesión social y la solidaridad. Sin embargo, son escasas las investigaciones que han analizado el impacto de las reformas de estos servicios focalizando en dichos aspectos. Este artículo ofrece una aproximación innovadora para explorar estas cuestiones, a partir del análisis y el contraste de las preferencias declaradas (satisfacción de los ciudadanos) y las preferencias reveladas (gasto) con dos de estos servicios, como son electricidady telecomunicaciones, en dos grandes países europeos: España y el Reino Unido. En telecomunicaciones, pero en mucha menor medida en electricidad, se obtiene evidencia de cómo las reformas han dado lugar a una Europa de "dos velocidades", con una situación en la cual los ciudadanos de mayor edad, los no ocupados y los de menor nivel educativo se comportan de manera diferente en el mercado, obteniendo como resultado una menor satisfacción con estos servicios que sus homólogos de menor edad, ocupados o con mayor nivel educativo. 


\section{Introduction}

Public infrastructure services - such as electricity and gas, water, communications and public transportation - experienced an extended period of stability in their modes of organization and regulation in Western European countries from around the end of World War II to the late 1970s (Millward 2005). During this period, the dominance of public ownership of these sectors was justified by arguments about the existence of market failures (in particular, natural monopolies), the strategic and economic importance of many of the services, as well as concerns about social justice (Comín and Díaz-Fuentes 2004, Van de Walle 2009). Public ownership helped act as a regulatory mechanism to resolve the conflict of interest between investors and consumers (Newbery 2004). However, from the late 1970s onwards, these services were subjected to deep reform. In the context of the European Union, this reform intensified sharply during the 1990s, particularly due to processes of market integration and liberalization policies in these sectors (Bauby 2008, Bognetti and Obermann 2008). In parallel, Member States embarked upon the privatization of many of these services.

Reform of public infrastructure services, particularly liberalization, deregulation and privatization, was founded on neoclassical economic theory which rested on two critical sets of assumptions. Firstly, it assumed that exposing firms to competition would result in lower prices and increased service choice for consumers. Both from the theoretical perspective (Armstrong and Sappington 2006) as well as ex-post empirical analysis of price and choice (Fiorio and Florio 2009), it has been shown that these reforms did not necessarily always deliver the promised results. Secondly - and more importantly for this article - it was assumed that citizens, cast as rational consumers, would be positioned to benefit universally from these developments (EC 2004). From the outset of reform, however, concern had been expressed by some agents about whether, under market-driven rules, traditions of public service obligations and universal access would be undermined, and that citizens' would end up receiving lower quality services (CEEP and ETUC 2000). Pressure was placed upon the European Commission (EC) to guarantee certain service standards, in the form of a directive or citizens' charter: after a series of consultations, communications and white papers, the EC officially recognized in a protocol of the Treaty of Lisbon that "Services of General Interest" were key to the upholding of social and territorial cohesion, strengthening solidarity and equity, thus preserving values such as universal access, affordability, quality and continuity were stated to be priorities (EC 2007a).

Now, despite the fact that reform was implemented in the name of the consumer, relatively little effort went into evaluating these reforms from the citizen, or even, the consumer, perspective (Fiorio and Florio 2008, Clifton and Díaz-Fuentes 2010). This relative neglect has started to change recently, spurred by two main developments. Firstly, the EC has officially recognized that problems remain in making the market work, particular, in these infrastructure services (Dierx et al., forthcoming). Secondly, policy-makers have become interested in how theoretical insights borrowed from behavioral economics might be applied to improving ongoing reform by better understanding consumer behavior. Interest in behavioral economics by policy-makers started among the Anglo-Saxon oriented institutions, including the Australian Government (2007), the Federal Trade Commission (2007), the Institute for 
Government (2010), as well as the OECD (2008 and 2010). ${ }^{1}$ From there, ideas were diffused to the EC, which became interested in how these insights could be used to improve public infrastructure regulation, in order to make the market work more efficiently whilst improving citizen well-being and satisfaction (EC 2008a and 2010).

This new approach, moreover, was mooted as being able to help to develop policies to address emerging concerns such as "vulnerable consumers". Vulnerable consumers, as defined by Andreasen and Manning (1990), are those who "are at a disadvantage in exchange relationships where that disadvantage is attributable to characteristics that are largely not controllable by them." Burden (1988) argued that vulnerability in the act of consumption can be traced to two, sometimes co-existing, causes: on the one hand, some consumers find it more difficult than others to obtain or assimilate the necessary information when taking decisions about good or service consumption; on the other hand, certain consumers are exposed to a higher risk of worsening their own welfare when taking inadequate consumption decisions. The interest in analyzing potential vulnerability can be justified by the need to advance our understanding of what precisely constitutes consumer vulnerability, which attributes and other factors it is associated with, and how these can place certain consumers in a disadvantaged position in the market place. Hogg et al. (2007) argue that globalization and the knowledge society have dramatically increased the complexity and information asymmetry surrounding consumptions decisions. Thus, the notion of consumer vulnerability is of great relevance for this article. However, the causes of vulnerability are not directly observable. Instead, vulnerability is usually analysed through the study of how particular characteristics of citizens or people in households may render them potentially vulnerable as consumers (Brennan et al. 2008). Hence, in this article, we follow Burden (1998) and the OECD (2008) and use these characteristics as proxies in order to enquire whether they do indeed cause consumer vulnerability, as explained further in the section on methodology.

In this light, the objective of this article is to evaluate public infrastructure regulation from the perspective of citizens as consumers, focusing particularly on consequences for equity and social cohesion. In order to examine how socio-economic differences affect expenditure and satisfaction, the analysis focuses on the decisions and attitudes of those potentially becoming "vulnerable consumers" through their belonging to three dimensions: those who do not work; the elderly; and/or the less-educated. We focus on two major infrastructure services where reforms have been particularly intense, telecommunications and electricity, and consider two large European countries where reform is advanced, the United Kingdom (UK), reform pioneer in the European context, and Spain, which also implemented deep reforms, albeit later, during the 1990s.

The rest of the article is structured as follows. The second sketches the extent of reform of telecommunications and electricity in the UK and Spain before explaining how behavioral economics and its insights could be applied in an effort to better understanding consumer behavior in these markets. The third section presents the data used and the methodology. Next, an empirical examination is conducted of the impact of socio-economic dimensions that have been associated with greater consumer vulnerability, through contrasting stated preferences (dissatisfaction with price) and revealed preferences (spending decisions), in the fourth section. Finally, in the conclusions, findings are presented, together with conclusions and future research questions.

\footnotetext{
${ }^{1}$ On the argument the OECD was born and fundamentally remains an Anglo-Saxon institution, see Clifton and Díaz-Fuentes (2011).
} 


\section{Rethinking the regulation of telecoms and electricity}

\subsection{Reforming telecoms and electricity in the UK and Spain}

The UK and Spain represent two major European economies where reforms in the telecommunications and electricity sectors were intense and far-reaching. The UK was the reform pioneer in Europe; Margaret Thatcher set into motion an ambitious programme including liberalization, deregulation and privatization from the 1980s (Florio 2004). Intense reform of these sectors in Spain followed, during the 1990s, responding in particular to the requirements of the EC liberalization directives (Clifton, Comín and Díaz-Fuentes 2006 and 2007, Dubois and Saplacan 2010). Across Europe, reform came earlier and deeper in telecommunications than in electricity (Bance 2007). In parallel, the telecommunications industry underwent profound technological change including convergence of sound, data and image from the 1970s (Mansell, 2009), setting into motion the introduction of multiple new options for consumers, such as the mobile phone and the internet, as well as new approaches to consumer contracts and billing households. In both countries, telecommunications reform resulted in total privatization and full legal liberalization of the sector. In practice, however, the former incumbents in both countries still enjoy high market concentration, particularly Telefónica, distorting competition (Clifton, Comín and Díaz-Fuentes 2011). In the electricity sector, both countries implemented full entry liberalization and unbundling. In the UK, privatization was total, whereas, in Spain, though far reaching, electricity transmission remained in the public sector. Whilst competition has generally been introduced in the UK, the Spanish market has remained dominated by private regional monopolies $^{2}$ (CEEP 2010). Rather than full withdrawal from these services, the State took on the role as market regulator and supervisor (Majone 1996) assuming overall responsibility for preserving citizens' rights as consumers to those services considered in the general interest. In Spain, the functioning of these markets is subject to legallyestablished public service obligations, which mainly refer to guaranteeing service universality and security of supply (CEEP 2010). In contrast, in the UK, citizens' rights as consumers are not enshrined in a specific legal document, and there was confidence that these issues could be resolved by the market (Clifton, Comín and Díaz-Fuentes 2005).

\subsection{The challenge from behavioural economics}

Through its competence in delivering the Single Market, the EC has substantial powers to implement bold reform across public infrastructure services such as telecommunications and electricity. These policies, based on a supply-side perspective, had as key objectives the promotion of market integration and the subsequent opening up to competition (Pelkmans 2006). Following conventional neoclassical economic theory, citizens, recast as consumers, were conceptualized as homo oeconomicus, meaning that they were conceptualized as being as rational agents who would maximize their individual utility. As such, EC policy-makers, just like their peers implementing similar reforms world-wide, assumed that benefits of introducing competition could be shared in similar ways by all (EC 2004). Little attention, if any, was paid to the notion that consumers did not necessarily respond in rational ways to the market, or that

2 RD 485/2009 and RD-Ley 6/2009 require, from 1 July 2009, that the Spanish electricity sector is open to competition. However, these changes have not yet had an impact on market performance. 
consumers, being heterogeneous, may respond in diverse ways to the same reform package.

Behavioral economics, a newly emerging discipline, challenged this conception of rational, selfish individuals. This school was, in turn, influenced by the institutionalist school, which had traditionally constituted the main alternative to the conventional neoclassical approach (Hodgson 1998). Institutionalism conceives individuals not as isolated elements, but as agents, whose behavior can be largely explained by their position in the social environment and by the socio-economic institutions around them, including interaction between individuals, the existence of common concepts, norms, values and customs (Wilbur and Harrison 1978, Hodgson 2000).

Whilst still maintaining many similarities with neoclassical economics, behavioral economics shares two core aspects with institutionalism: it incorporates insights from other scientific disciplines, particularly psychology; and it foregrounds the empirical reality of agents' behavior, rather than resting principally on theoretical formalizations (Berg 2010). On these grounds, the existence of biases that may condition individual behavior are identified such as "bounded rationality", because of overconfidence, inertia, extrapolation error or loss aversion, and "limited selfishness", due to altruism, cooperation or inequality aversion (Mullainathan and Thaler 2000). Insights from behavioral economics can be particularly interesting when analyzing situations in which individuals' decisions do not lead to their optimizing their situation. A case in point is that the benefits of competition may not occur when consumers do not behave in perfectly rational and do not enjoy perfect information (Gans 2005).

Kahneman and Thaler (2006) distinguished between a "decision utility", on which agents base their choices, and "experienced utility", referring to the results obtained from these decisions. Combining insights from behavioral economics on bounded rationality and limited selfishness with institutionalists' analysis of how the social environment influences consumers' behavior, it could be derived that consumers will take heterogeneous decisions, and that not all consumers have the same capabilities to make consumption choices that lead them to maximize their own satisfaction.

To date, the evaluation of public infrastructure reform and regulation has scarcely applied these concepts. However, as Ceriani, Doronzo and Florio (2009) observed, analyzing consumer heterogeneity could be particularly useful in these sectors, due to ease of implementing price discriminations, and multiple uses of services, leading to very different demand elasticities. The EC (2008a and 2010) has already started to show an interest in the possibilities of behavioral economics for future improved implementation of the Single Market. At best, they envisage that a better understanding of citizens as consumers in the marketplace might help the formulation of specific, targeted consumer policies to facilitate certain categories of citizens take better consumption decisions (EC 2008b, OECD 2008).

\section{Data and Methodology}

There are two main empirical sources at hand when seeking to examine choices and attitudes of individuals when consuming public services: revealed preferences, information on observable choices made by individuals; and stated preferences, derived from subjective expressions of satisfaction with public services, based on opinions (Frey and Stutzer 2002). Both options, taken alone, have various limitations, which have led to a debate about which is the best suited method of analyzing individual and social welfare. This article uses an innovative approach of using revealed and stated 
preferences together, as complementary sources, to evaluate reform in these sectors, as suggested by Fiorio and Florio (2008). This approach has already been successfully applied in other fields (Köszegi and Rabin 2008, Whitehead et al. 2008), but it has scarcely been applied to the evaluation of public infrastructure services regulation from the citizens' perspective, and what has been done to date is largely confined to one sector and one country (Waddams Price et al. 2007).

Revealed preferences are often understood as representing objective data, so most economic analysis has focused on these. ${ }^{3}$ Most of the studies that have used revealed preferences to evaluate public infrastructure services regulation are based on national Household Budget Surveys (HBSs), essentially, surveys disaggregating household expenditure by categories. In Spain, studies include Arocena (2003) and Duarte, Mainar and Sánchez-Chóliz (2010); and in the UK, Gómez-Lobo (1996), Burns, Crawford and Dilnot (1996), Waddams Price and Hancock (1998) and Bennett, Cooke and Waddams Price (2002). However, taken alone, revealed preferences do not permit observers to analyze behavioral aspects such as why a service is not used, or to understand how biases identified by behavioral economists lead to individuals not maximizing their utility. Moreover, public infrastructure service markets are not competitive, but quasi-markets, so exiting and switching supplier involve high costs for the citizen and, thus, consumption decisions may not always reflect their real preferences. In this way, Hirschman's exit-voice-loyalty framework (1970) is invoked, since voice, which can be evaluated using stated preferences, is also an essential element to consider. Once public infrastructure reform was set in motion, the EC executed Eurobarometer surveys specifically intended to analyze and keep a check on citizen satisfaction with these services. Some economic analysis, such as Clifton, Comín and Díaz-Fuentes (2005), Bacchiocchi, Florio and Gambaro (2008), Fiorio and Florio $(2008,2009)$ and Clifton and Díaz-Fuentes (2010) have used these sources to examine citizen satisfaction with reform. The theoretical advantage of combining stated and revealed preferences is to maximize the contrasting strengths of both approaches, whilst minimizing their weaknesses, thus aiming to enrich the interpretation of the data (Whitehead et al. 2008: 876).

The evaluation of infrastructure reform from a consumer perspective is executed by contrasting examinations of revealed and stated preferences: firstly, the two data sources are analysed separately; next, they are contrasted. The logic of the analysis follows Kahneman and Thaler (2006) who state that, in the decision-making process, individuals first make their choices, reflected in revealed spending patterns; they then obtain a degree of (dis)satisfaction with the price of that service, which is reflected in stated preferences. In order to derive hypotheses for testing, we reverse the order of these two steps to propose:

1. Citizens who are more potentially vulnerable as consumers will be more dissatisfied than other citizens with service prices, as a result of the spending decisions they take in the markets and reflecting the particular problems they encounter in these markets.

2. Citizens who are more potentially vulnerable as consumers make spending decisions which are distinct to those of other citizens.

\footnotetext{
${ }^{3}$ For an interesting debate on the objective/subjective nature of data on public sector performance, see the special issue edited by Van Dooren and Van de Walle (2008).
} 
3. The problems of citizens who are more potentially vulnerable as consumers in the market are commonly observed in both countries and sectors under analysis.

Empirical analysis of the three hypotheses is addressed firstly by evaluating stated preferences. Sources used are the sub-samples of the micro-data for the year 2006, from Eurobarometer, henceforth, referred to as EB (EC 2007b). Dissatisfaction with service price is selected as the dependent variable, identified when the respondent states that the service is not "affordable". In the case of telecommunications, information is disaggregated between fixed telephony, mobile telephony and the internet (which is the least-used service of the three). Because of this, two variables are considered: "dissatisfaction with the price of telephony", which refers to dissatisfaction with the price of fixed or mobile telephony, and "dissatisfaction with the price of telecommunications", referring to dissatisfaction with the price of one of any of these three services. For revealed preferences, data is derived from the micro-data for 2006 from the British and Spanish HBSs, namely, the Expenditure and Food Survey (ONS 2006) and the Encuesta de Presupuestos Familiares (INE 2006). From the information included in these surveys, the logarithm of household spending on electricity and telecommunications, expressed in euros per year, is taken as the dependent variable. With respect to the independent variables, of particular importance are those socioeconomic characteristics which can be used as proxies of vulnerability. Following the definition of consumer vulnerability included in the first section, Burden (1998) identified six socio-economic characteristics which could be potentially associated with consumer vulnerability: age (both the elderly, and younger consumers); education (lack of formal study); income (low income); employment status (unemployment); health (restrictions caused by poor health); and ethnicity (ethnic minorities). In a report on consumers and telecommunications, the OECD (2008) included four of these categories: elderly/young, low income, unemployment and health/disability, whilst it also used rural residence.

In this article, we select three major independent variables which may be associated with creating more difficulty and potential risks for consumers in the market place: employment (the employed versus the unemployed, represented by NOTEMPLOYED in the EB and NONEMPLOYED in the HBSs); age (contrasting the elderly, the middle-aged and the young); and education (contrasting those with low educational levels as the reference category with the better educated, represented by independent variables HIGHSECOND (Higher Secondary Education) and UNIVERSITY, which, in the HBSs, are described for the reference person (RP) of the household. The selection of these three variables here, apart from their previous selection by other researchers (Burden, 1998; OECD, 2008) is justified by the fact that there is adequate information on them in both sources as regards availability of information, quality, homogeneity among the sources and the existence of a large enough percentage of the sample size in each case. As regards the category of employment, we expand the use of Burden (1998) and OECD (2008) from "unemployees" to the "non-employed", to encapsulate the situation of those who do not work, rather than only those unemployed who are actively looking for work. Unfortunately, our data sources do not provide sufficient or comparable information on other possible proxies for consumer vulnerability, such as belonging to an ethnic group, health/disability and rural residence. Though the HBS includes income, the EB does not, so income is used as a control variable for the RP in our analysis, rather than an independent variable. Thus, this paper does not attempt to analyse all socio-economic 
characteristics which could be associated with consumer vulnerability, rather, how three major socio-economic attributes of consumers might be associated with their potential vulnerability in the market place. Control variables are household size and house ownership status (NOHOUSEPROP means those not owning their house, versus home owners) and, in the case of revealed preferences, household income (from the logarithm of the equivalent total expenditure, InSPENDequiv). The effect of each of these variables on the dependent variables is derived from a probit estimation, in the case of stated preferences, and from a linear estimation, in the case of revealed preferences. In both cases, for telecommunications and electricity, separate estimations are conducted for both countries, using the sampling weights provided by the surveys, ensuring representative results in terms of the whole population.

Finally, in order to contrast the evidence obtained, as regards stated preferences, it is considered that dissatisfaction with service price is a direct function of two elements: the unit price paid $(P)$; and a second, subjective element $(V)$, which reflects the degree of pessimism in the perception, which can be derived by the respondent's level of confidence in the market. For revealed preferences, spending on each service is also a direct function of the unit price paid $(P)$ and, in addition, of the amount consumed $(X)$, reflecting the degree of participation in the market. From the two relationships described, it becomes possible to interpret the effects estimated regarding the dependent variables under analysis as a result of differences in $P, V$ and/or $X$ and, thus, reflecting particular problems in the market.

\section{Evaluating telecoms and electricity services from the citizens' perspective: Results}

The estimated marginal effects of the independent variables analyzed on stated dissatisfaction with service price are shown in Table 1. In the case of electricity, the variables representing citizens' potential vulnerability as consumers (employment, age and education) hardly show any significant effects on price dissatisfaction. In Spain, 65year olds and over are slightly more dissatisfied than others, but in the UK, dissatisfaction is independent of age. Dissatisfaction among the employed and nonemployed is similar in both countries. In the case of education, there are, again, no significant differences across the two countries, with the minor exception of the UK where there is a weakly significant effect associated with an intermediate educational attainment.

In contrast, in the case of telecommunications, all the variables representative of citizens' potential vulnerability as consumers are significantly related to price dissatisfaction, independent of the indicator selected (price of telephony or price of telecommunications). Furthermore, all these effects show the same direction in both countries. So, those not employed express greater dissatisfaction than the employed in the UK and Spain. As regards age, there are higher dissatisfaction rates for the 65 year olds and over in both countries: disaggregating the services, the elderly are particularly dissatisfied with both mobile telephony and internet. Those over 75 years old are even more dissatisfied than those between 65 and 74. Finally, educational attainment is inversely related to price dissatisfaction in both countries. When considering the price of telephony, those without university education are less satisfied than graduates. For the price of telecommunications, those who did not finish secondary school show particular dissatisfaction. 
Table 1. Marginal effects estimated on dissatisfaction with electricity and telecommunications prices

\begin{tabular}{|c|c|c|c|c|c|c|c|}
\hline & & \multicolumn{2}{|c|}{ Electricity } & \multicolumn{2}{|c|}{ Telephony } & \multicolumn{2}{|c|}{ Telecommunications } \\
\hline & & UK & Spain & UK & Spain & UK & Spain \\
\hline & Variable & $\begin{array}{l}\text { Marg. } \\
\text { Eff. }\end{array}$ & $\begin{array}{l}\text { Marg. } \\
\text { Eff. }\end{array}$ & $\begin{array}{l}\text { Marg. } \\
\text { Eff. }\end{array}$ & $\begin{array}{l}\text { Marg. } \\
\text { Eff. }\end{array}$ & $\begin{array}{l}\text { Marg. } \\
\text { Eff. }\end{array}$ & $\begin{array}{l}\text { Marg. } \\
\text { Eff. }\end{array}$ \\
\hline Employment & NOTEMPLOYED & 0.036 & -0.020 & $0.081 * *$ & $0.107 * * *$ & $0.092 * *$ & $0.067 *$ \\
\hline \multirow[t]{4}{*}{ Age } & $<35$ & 0.036 & -0.011 & 0.031 & -0.046 & -0.008 & -0.072 \\
\hline & $50-64$ & 0.007 & -0.018 & 0.042 & -0.005 & $0.118 * *$ & -0.018 \\
\hline & $65-74$ & 0.070 & $0.125^{*}$ & $0.133 * *$ & $0.175 * * *$ & $0.303 * * *$ & $0.163 * * *$ \\
\hline & $>74$ & -0.024 & $0.182 * *$ & $0.295 * * *$ & $0.286 * * *$ & $0.445 * * *$ & $0.214 * * *$ \\
\hline \multirow[t]{2}{*}{ Education } & HIGHSECOND & $0.049 *$ & 0.037 & -0.032 & -0.061 & $-0.067 *$ & $-0.094 * *$ \\
\hline & UNIVERSITY & -0.033 & -0.041 & $-0.099 * *$ & $-0.129 * *$ & $-0.157 * * *$ & $-0.214 * * *$ \\
\hline Control & 1PERSON & 0.014 & 0.069 & $0.125 * * *$ & -0.010 & $0.136^{* * *}$ & 0.020 \\
\hline \multirow[t]{4}{*}{ Variables } & 3PERSONS & 0.057 & 0.009 & 0.022 & $-0.105 * *$ & 0.018 & -0.068 \\
\hline & 4PERSONS & $0.085^{*}$ & $0.093 * *$ & -0.049 & -0.024 & -0.090 & -0.063 \\
\hline & $>4$ PERSONS & 0.027 & 0.006 & 0.059 & $-0.105^{*}$ & 0.026 & -0.097 \\
\hline & NOHOUSEPROP & 0.005 & $0.158 * * *$ & $0.149 * * *$ & $0.203 * * *$ & $0.166^{* * *}$ & $0.145 * * *$ \\
\hline $\mathbf{N}$ & & 1337 & 1006 & 1337 & 1006 & 1337 & 1006 \\
\hline Wald chi2 & & 20.46 & 34.29 & 125.57 & 111.03 & 200.99 & 105.32 \\
\hline Prob > chi2 & & 0.059 & 0.001 & 0.000 & 0.000 & 0.000 & 0.000 \\
\hline
\end{tabular}

* Significance level at $10 \%, * *$ significance level at $5 \%, * * *$ significance level at $1 \%$

Source: Own calculations based on EC (2007b).

Next we turn to examining correspondence between the estimated effects of these variables on revealed service expenditure. Results are shown in Table 2. Starting with expenditure on electricity, the control variables show significant effects in both countries. The variables representing citizens' potential vulnerability as consumers are also related, in general, to expenditure on this service. Age is directly related to electricity expenditure in both countries, especially in the UK, which may be explained by lifestyle if we assume the elderly spend more time at home and, possibly, by the overall generally colder climate in the UK. Regarding employment status, households without any employed member are associated with higher spending in Spain, although not in the UK. Moreover, the less-educated spend more on electricity in Spain, but less in the UK, especially in comparison to those with university education. Our previous results for stated preferences in Table 1 showed the absence of significant relationships between these variables and price dissatisfaction. It follows that they are also not related to $P$ and $V$, the two elements into which price dissatisfaction can be decomposed. This, in this case, the estimated effects of variables representative of vulnerability on spending on electricity can be interpreted, as those related to the control variables, mainly as a result of the differences in the amount of service consumed $(X)$. As an exception, the elderly in Spain were observed to be more dissatisfied with electricity prices, corresponding to their higher spending on the service.

For telecommunications, those variables associated with consumer vulnerability, already shown to be significantly related to price dissatisfaction, were also seen to be related, in general, to spending. In both countries, the elderly spend more on telephone services: disaggregating this, they spend much more on fixed telephony, much less on mobile telephony and even less on internet services. Thus, controlling for income, 
employment status, education, household size and so forth, the elderly use fixed telephony services more intensively, rather than using alternative communications services. This behaviour would seem to be best explained by inter-generational lags and inertia vis-à-vis the take-up of the new technologies, reinforcing evidence of consumer heterogeneity. Elderly people's dissatisfaction with these two services is linked to their lack of participation in these markets: many may use fixed telephony to make expensive connections to mobile telephones, for instance. For sure, their spending decisions do not lead them to optimise their savings, thus minimise their own dissatisfaction.

As regards employment status, those households with no employed member and, to a lesser extent, households with one employed member, spend less on telecommunications in both countries, which can be explained by their negative perceptions about affordability. Finally, with regard to education, lower levels of education are associated with lower spending on telecommunications in Spain, though not in the UK. Simultaneously observed higher levels of dissatisfaction and lower spending on telecommunications among the household with no employed members, and, in Spain, also among the lower-educated, are interpreted necessarily as being derived from a more pessimistic perception $(V)$ and/or lower amount consumed of the service $(X)$, apart from possible differences in the unit price $(P)$. Consequently, the combined evidence indicates that citizens face problems in the telecommunications markets, reflected in lower confidence (linked to the higher $V$ ) and/or lower participation (related to the lower $X$ ). In the case of lower-educated in the UK, the problems reflected by higher dissatisfaction can be interpreted as being derived from $V$, although differences may also exist in $P$ and $X$.

Table 2. Effects estimated on spending on electricity and telecommunications Electricity Telecommunications

\begin{tabular}{llllll} 
& & UK & Spain & UK & Spain \\
\hline & & Coeff. & Coeff. & Coeff. & Coeff. \\
\hline \multirow{2}{*}{ Employment } & ONEEMPLOYED & $-0,002$ & 0,031 & $-0,158^{* * *}$ & $-0,157^{* * *}$ \\
& NONEEMPLOYED & $-0,123$ & $0,160^{* * *}$ & $-0,447^{* * *}$ & $-0,325^{* * *}$ \\
\hline \multirow{2}{*}{ Age } & RP $<35$ & $-0,016$ & $-0,115^{* * *}$ & $-0,013$ & 0,044 \\
& RP 50-64 & $0,435^{* * *}$ & $0,073^{* * *}$ & 0,030 & $0,220^{* * *}$ \\
& RP 65-74 & $0,759^{* * *}$ & $0,114^{* * *}$ & $0,148^{*}$ & $0,227^{* * *}$ \\
& RP $>74$ & $1,002^{* * *}$ & $0,105^{* *}$ & $0,270^{* * *}$ & $0,243^{* * *}$ \\
\hline Education & RP HIGHSECOND & 0,076 & $-0,057^{* *}$ & $-0,010$ & $0,132^{* * *}$ \\
& RP UNIVERSITY & $0,187^{* * *}$ & $-0,137^{* * *}$ & 0,018 & $0,171^{* * *}$ \\
\hline Control & NMEMBERS & $0,221^{* * *}$ & $0,365^{* * *}$ & $0,353^{* * *}$ & $0,508^{* * *}$ \\
Variables & NMEMBERS2 & $-0,004$ & $-0,023^{* * *}$ & $-0,022^{* * *}$ & $-0,033^{* * *}$ \\
\cline { 2 - 6 } & NOHOUSEPROP & $-0,784 * * *$ & $-0,281^{* * *}$ & $-0,159^{* * *}$ & $-0,156^{* * *}$ \\
\cline { 2 - 6 } & lnSPENDequiv & $0,613^{* * *}$ & $0,757^{* * *}$ & $0,616^{* * *}$ & $0,932^{* * *}$ \\
\hline $\mathbf{N}$ & & 6645 & 19435 & 6645 & 19435 \\
$\mathbf{F}$ & & 52,97 & 387.65 & 85,09 & 369,80 \\
Prob $>\mathbf{F}$ & & 0 & 0 & 0 & 0 \\
\hline
\end{tabular}

$\mathrm{RP}=$ Reference Person

* Significance level at $10 \%, * *$ significance level at $5 \%, * * *$ significance level at $1 \%$

Source: Own calculations based on INE (2006) and ONS (2006). 


\section{Conclusions}

Results obtained are now applied to address the three hypotheses. The first stated that those citizens more potentially vulnerable as consumers would express higher levels of dissatisfaction with these services. In the case of telecommunications, it was shown that those not working, the elderly and the lower-educated, were indeed more dissatisfied with prices. These findings coincide with the study by Bacchiocchi, Florio and Gambaro (2008) on satisfaction with fixed telephony in the EU-15 between 2000 and 2004, the main difference being that, in our contribution, mobile and internet communications were also included. Their inclusion turned out to be important, as some of the most potentially vulnerable of consumers, the very elderly, are sharply dissatisfied particularly with them. It seems that a combination of issues including technological change and product innovation, affordability and intergenerational difference help explain greater reluctance to use these new communications services, as will be discussed below. In contrast, for electricity, no significant associations were found between potentially vulnerable consumers and price dissatisfaction in the two countries selected for 2006. Other research, such as Fiorio and Florio (2008), found that the unemployed and less-educated were less satisfied with electricity prices, whilst the very elderly were more satisfied, in the EU15 in an earlier period (2000 to 2004). The second hypothesis posited that those more potentially vulnerable as consumers would make different spending decisions than other citizens. On contrasting stated and revealed preferences, different interpretations can be derived from the evidence. For telecommunications, the most potentially vulnerable citizens expressed high levels of dissatisfaction which was associated with their different spending decisions. In the cases of those who do not work and lower-educated people, high dissatisfaction is related to their lower levels of confidence and/or lower participation in the market. As regards the elderly, this category reveals differences when taking decisions about spending on mobile and internet communications. Decisions to spend instead more on traditional, fixed telephony are associated with their high dissatisfaction levels with the alternative services. In contrast, for electricity, the differences observed are derived, in general, from differences in the amount consumed, as there are very few significant effects on price dissatisfaction. Finally, in relation to the third hypothesis, which posited that the problems exhibited by people in socio-economic categories associated with vulnerability would be similar across the two countries, this was found to be generally correct for telecommunications, whereas the evidence on electricity was more mixed.

The differences observed between the telecommunications and electricity sectors merit some explanation. First, in the case of telecommunications, dramatic technological innovation has been accompanied by the introduction to the market place of new communications services, revolutionizing the ways in which people may communicate whilst posing increasingly complex consumption decisions. This combined with privatization, liberalization and competition policies - means that consumers face a world of diverse, partially substitutable technical products of multiple potential providers. The consumption decision of whether to communicate, how, when, for how long and why - a relatively straightforward one in the age of the fixed telephony provider in the age of the national monopoly regime - has evolved into one where consumers face a barrage of (over) information, not just about the initial consumption decision but also questions about contractual and billing 
processes. Whilst the electricity sector, in contrast, has not stood still in technological terms, consumers do not have comparable choices: whilst consumers are faced with the option of sending an email, an SMS message, or making a mobile or fixed call, electricity is a single product. Moreover, public policy reform has come much earlier on in the telecommunications sector than in the electricity sector, whilst telecommunications reform was quite swift whereas in electricity it has been partially blocked. Both in Spain and the UK, consumers could benefit from choice in telecommunications supplier much earlier than they could from choice in electricity supply. In the UK, consumers had options to switch several years before they could in Spain; nevertheless, a study by Waddams and Wilson (2010) showed that proxies of potential consumer vulnerability, particularly lower educational attainment, had restricted switching activity in 2005. In Spain, consumers only started to have the option to choose among multiple providers from 2009, three years after the year under study here. Nevertheless, this result requires more analysis, which the authors are presently conducting for twelve EU Member States in the same year for telecommunications, electricity and gas.

Moreover, the findings reinforce a basic observation: common policy reforms and regulation can have different effects on citizens, who are heterogeneous, and thus do not necessarily behave in a uniform and rational manner. On entering the market, individuals do not have the same capacity or social environment to enable them to maximize their satisfaction. Citizens, as suggested by institutionalists, have different social, cultural and cognitive backgrounds. They are conditioned by their different social and relational environments, and this influences the processes of decisionmaking. This statement can be combined with the new insights from Behavioural Economics regarding biases in decision making that lead to behaviour which is not always perfectly rational and selfish. Thus, it can be derived that, on entering the market, individuals do not have the same capacity or social environment to enable them to maximize their satisfaction: certain socio-economic groups, therefore, may be more potentially vulnerable as consumers. In our findings here, potentially vulnerable groups have found the new environment in the telecommunications market of particular complexity, much more so than in the electricity market, which, though it has undergone reform, earlier in the UK than Spain, has not experienced equivalent technological change leading to product innovation such as mobile and internet communications.

These findings are also significant from the perspective of policy-makers. Telecoms and electricity reform and regulation were designed from the supply-side, and little or no attention was paid to citizens' heterogeneity as consumers. The central issue is that, in the absence of compensatory regulatory policies, these reforms can have a negative impact on public service obligations, including issues of service universality and affordability. Of more concern still, it is, in general, those individuals who are potentially vulnerable in the market who may find their vulnerability increases. Given the EC holds that these services are amongst those understood as key to ensuring equity, solidarity and social cohesion (EC 2007a), the task of enquiring how reform of these sectors affects certain socio-economic groups associated with consumer vulnerability is an important one for the future evolution of public policy in the European Union.

Finally, the findings obtained point to the need to continue to redefine EC regulatory policies in these sectors, particularly by incorporating better insights on consumer heterogeneity in the design, implementation and evaluation of policy. Already, in recognition of the emergence of new issues as a consequence of the 
reform of public infrastructure services, some new regulation and programs have been implemented by governments and firms targeting consumers in particular socioeconomic groups. In the UK, in the electricity sector, the electricity and gas regulator, OFGEM, launched a "Social Action Strategy" from 2000, in response to emerging evidence on problems such as unaffordable energy prices to the most potentially vulnerable (OFGEM 2010). The British government has offered "Cold Weather Payments" during periods of particularly cold weather for those on low incomes. In the telecommunications sector, the ex-incumbent, BT, launched a service called "BT basic" from 2008, offering low-cost rental lines with restricted calls to the unemployed and pensioners. In Spain, the National Commission of Energy (CNE) offered, in 2010, a "social voucher" to consumers considered potentially vulnerable, effectively maintaining 2009 prices, whilst they increased by 10 per cent for the rest of the population (CNE 2010). A "social voucher" was also established by the Telecommunications Market Commission (CMT 2010) for the lowest-income pensioners from 2007. Telefónica, Spain's ex-incumbent, also offered discounts on mobile telephone bills to the unemployed during 2009 and 2010, with the aim these consumers would continue to use the service during the crisis (discontinued in October 2010). But most of these policies are ad-hoc, patchy and partial solutions.

As reform of public infrastructure services continues to deepen in electricity and gas, as well as water, it could be envisaged that the problems potentially vulnerable consumers face in these markets may increase. Future lines of research should continue to evaluate the reform of public services from the citizen perspective, in a sense, tracking the advantages and disadvantages of reform, and signalling or mapping experiences of the more potentially vulnerable consumers with a view to evaluating the extent to which regulation and social programmes succeed or not in ameliorating any negative effects of reform on the potentially vulnerable amongst us.

\section{References}

ARMSTRONG M. and SAPPINGTON D., 2006, "Regulation, Competition and Liberalization", Journal of Economic Literature, XLIV, 325-366.

AROCENA P., 2003, "The Reform of the Utilities Sector in Spain”, in Ugaz, C. and Waddams Price, C., eds., Utility Privatization and Regulation: A Fair Deal for Consumers?, Northampton, Edward Elgar.

AUSTRALIAN GOVERNMENT, 2007, Behavioural Economics and Public Policy, Australian Government Productivity Commission, Melbourne, August 8-9.

BACCHIOCCHI, E. FLORIO, M. and GAMBARO, M. 2008, "Telecom Prices, regulatory reforms and consumers' satisfaction: evidence for 15 EU countries", DEAS Working Papers, 2008-10, Dipartimento di Scienze Economiche Aziendali e Statistiche, Universitá degli Studi di Milano.

BANCE P., 2007, "Liberalization of European telecommunications: sectoral dynamics and structural mutations", Annals of Public and Cooperative Economics, 78 (3), 331-351.

BAUBY P., 2008, "L’européanisation des services publics", Télescope, 14 (1), 11-22.

BENNETT M., COOKE D. and WADDAMS PRICE C., 2002, "Left Out in the Cold? New Energy Tariffs, Low-Income Households and the Fuel Poor", Fiscal Studies, 23 (2), 167-194.

BERG N., 2010, "Behavioral Economics", in Free, R. C., ed., 21st century economics: a reference handbook, Thousand Oaks, SAGE Publications. 
BOGNETTI G. and OBERMANN G., 2008, "Liberalization and privatization of public utilities: origins of the debate, current issues and challenges for the future", Annals of Public and Cooperative Economics, 79 (3/4), 461-485.

BURDEN R., 1998, Vulnerable consumer groups: quantification and analysis, London, Office of Fair Trading.

BURNS, P. CRAWFORD, I. and DILNOT, A. 1996, "Regulation and Redistribution in Utilities", Fiscal Studies, vol. 16 (4), 1-22.

CEEP, 2010, Public services in the European Union \& in the 27 member states. Statistics, organization and regulations, URL: www.actionpublique.eu.

CEEP and ETUC, 2000, 'Proposal for a Charter of Services of General Interest', Brussels: CEEP and ETUC.

CERIANI L., DORONZO R. and FLORIO M., 2009, "Privatization, unbundling and liberalization of network industries: a discussion of the dominant policy paradigm in the EU", DEAS Working Papers, 2009-09, Dipartimento di Scienze Economiche Aziendali e Statistiche, Universitá degli Studi di Milano.

CLIFTON J., COMÍN F. and DÍAZ-FUENTES D., 2005, "Empowering Europe's Citizens? On the prospects for the Charter of Services of General Interest", Public Management Review, 7 (3), 417-443.

CLIFTON J., COMÍN F. and DÍAZ-FUENTES D., 2006, "Privatizing public enterprises in the European Union 1960-2002": ideological, pragmatic, inevitable? Journal of European Public Policy, 13 (5), 736-756.

CLIFTON J., COMÍN F. and DÍAZ-FUENTES D., 2007, eds., Transforming public enterprise in Europe and North America: Networks, Integration and Transnationalisation, New York, Palgrave-Macmillan.

CLIFTON J., COMÍN F. and DÍAZ-FUENTES D., 2011, "From national monopoly to Multinational Corporation: how regulation shaped the road towards telecommunications internationalization", Business History.

CLIFTON J. and DÍAZ-FUENTES, D., 2010, "Evaluating EU policies on public services: a citizens' perspective", Annals of Public and Cooperative Economics, 81 (2), 281-311.

CLIFTON, J. and DÍAZ-FUENTES, D., 2011, 'From "club of the rich" to "globalization à la carte": Evaluating reform at the OECD' Global Policy.

CNE (2010) "El Bono Social" http://www.cne.es/cne/contenido.jsp?id nodo $=407 \& \& \&$ keyword $=\&$ auditoria $=\mathrm{F}$, last accessed 10 February 2011

CMT (2010) "Order PRE/531/2007" http://www.cmt.es/cmt ptl_ext/SelectOption.do?tipo $=$ html\&detalles $=09002719800$ $\underline{87867 \& \text { nav }=\text { norma buscador\&categoria }=\text { Servicio } \% 20 \text { Universal, last accessed } 10}$ January 2011.

COMÍN F. and DÍAZ-FUENTES D., 2004, La empresa pública en Europa, Madrid, Síntesis.

DIERX, A., ILZKOVITZ, F. KOVACS, V. and SOUSA, N., (forthcoming) A European Single Market for the $21^{\text {st }}$ Century, London/New York/Delhi: Anthem Press.

DUARTE, R. MAINAR, A. and SÁNCHEZ-CHÓLIZ, J. (2010) "The impact of household consumption patterns on emissions in Spain" Energy Economics, 32 (1) 176-185.

DUBOIS U. and SAPLACAN R., 2010, "Public service perspectives on reforms of electricity distribution and supply: a modular analysis", Annals of Public and Cooperative Economics, 81 (2), 313-356.

EC, 2004, EU competition policy and the consumer. 
EC, 2007a, Treaty of Lisbon amending the Treaty on European Union and the Treaty establishing the European Community.

EC, 2007b, Eurobarometer 260: Consumers opinions on Services of General Interest, Brussels, EC.

EC, 2008a, How Can Behavioural Economics Improve Policies Affecting Consumers?, DG Health and Consumer Protection, Brussels, November 28.

EC, 2008b, Questions and Answers on Behavioural Economics, MEMO/08/748.

EC, 2010, Behavioural economics, so what: should policy makers care?, DG Health and Consumers, Brussels, November 22.

FEDERAL TRADE COMMISSION, 2007, Behavioral Economics and Consumer Policy, New Jersey, September 14.

FIORIO C. V. and FLORIO M., 2008, "Do you Pay a Fair Price for Electricity? Consumers' Satisfaction and Utility Reform in the EU", DEAS Working Papers, 2008-12, Dipartimento di Scienze Economiche Aziendali e Statistiche, Universitá degli Studi di Milano.

FIORIO C. V. and FLORIO M., 2009, "The reform of Network Industries, Privatization and Consumers' Welfare: Evidence from the EU15", DEAS Working Papers, 200941, Dipartimento di Scienze Economiche Aziendali e Statistiche, Universitá degli Studi di Milano.

FLORIO, M. 2004, The Great Divestiture: Evaluating the Welfare Impact of the British Privatizations, 1979-1997, Cambridge, MIT Press.

FREY B. S. and STUTZER A., 2002, "What Can Economists Learn from Happiness Research?", Journal of Economic Literature, XL, 402-435.

GANS J. S., 2005, "Protecting Consumers by Protecting Competition: Does Behavioural Economics Support this Contention?", MBS Working Papers, Melbourne Business School, University of Melbourne.

GÓMEZ-LOBO, A., 1996, 'The Welfare Consequences of Tariff Rebalancing in the Domestic Gas Market', Fiscal Studies, vol. 17 (4), 49-65.

HIRSCHMAN A., 1970, Exit, voice and royalty: Responses to decline in firms, organizations and states, Cambridge, Harvard University Press.

HODGSON G. M., 1998, "The approach of institutional economics", Journal of Economic Literature, 36 (1), 166-192.

HODGSON G. M., 2000, "What is the essence of institutional economics?", Journal of Economic Issues, 34 (2), 317-329.

HOGG M. K., HOWELLS G. and MILMAN D., 2007, "Consumers in the KnowledgeBased Economy (KBE): What creates and/or constitutes consumer vulnerability in the KBE?", Journal of Consumer Policy, 30 (2), 151-158.

INE (INSTITUTO NACIONAL DE ESTADÍSTICA), 2006, Encuesta de Presupuestos Familiares, Madrid, INE.

INSTITUTE FOR GOVERNMENT, 2010, Mindspace. Influencing behaviour through public policy, London, Cabinet Office.

KAHNEMAN D. and THALER R. H., 2006, "Anomalies. Utility Maximization and Experienced Utility”, Journal of Economic Perspectives, 20 (1), 221-234.

KÖSZEGI B. and RABIN M., 2008, "Choices, situations and happiness", Journal of Public Economics, 92, 1821-1832.

MAJONE, G., 1996, Regulating Europe, London: Routledge.

MANSELL, R., 2009, The Information Society, London: Routledge.

MILLWARD, R., 2005, Private and Public Enterprise in Europe: Energy,

Telecommunications and Transport, 1830-1990, Cambridge: Cambridge University Press. 
MULLAINATHAN S. and THALER R., 2000, "Behavioural economics", Working Paper Series, 00-27, Department of Economics, Massachusetts Institute of Technology.

NEWBERY D. M., 2004, "Privatising Network Industries", CESifo Working Papers, 1132, Center for Economic Studies \& Ifo Institute for Economic Research, Munich.

OECD, 2008, Enhancing Competition in Telecommunications: Protecting and Empowering Consumers, Paris, OECD.

OECD, 2010, Consumer policy toolkit, Paris, OECD.

OFGEM, 2010, Social Action Strategy: 2009-2010 update, London, OFGEM.

ONS, 2006, Expenditure and Food Survey, London, ONS.

$\mathrm{RD} 485 / 2009$, de 3 de abril, por el que se regula la puesta en marcha del suministro de último recurso en el sector de la energía eléctrica.

RD ley 6/2009, de 30 de abril, por el que se adoptar determinadas medidas en el sector energético y se aprueba el bono social.

PELKMANS J., 2006, European integration: Methods and economic analysis, Harlow, Prentice Hall.

VAN DOOREN W. and VAN DE WALLE S., 2008, "Reality is merely an illusion, albeit a persistent one: introduction to the performance measurement symposium", International Review of Administrative Sciences, 74, 531-534.

VAN DE WALLE S., 2009, "When is a service an essential public service?", Annals of Public and Cooperative Economics, 80 (4), 521-545.

WADDAMS, C. and WILSON, C., 2010, "Do Consumers Switch to the Best Supplier?", Oxford Economic Papers, 62: 647-668.

WADDAMS PRICE C., BRAZIER K., PHAM K., MATHIEU L. and WANG W., 2007, "Identifying Fuel Poverty using Objective and Subjective Measures", $C C P$ Working Papers, 07-11, Centre for Competition Policy, University of East Anglia.

WADDAMS PRICE C. and HANCOCK R., 1998, "Distributional Effects of Liberalising UK Residential Utility Markets”, Fiscal Studies, 19 (3), 295-319.

WILBUR C. K. and HARRISON R. S., 1978, "The methodological basis of institutional economics: pattern model, storytelling, and holism", Journal of Economic Issues, 12 (1), 61-89.

WHITEHEAD J. C., PATTANAYAK S. K., VAN HOUVTEN G. L. and GELSO B. R., 2008, "Combining revealed and stated preference data to estimate the nonmarket value of ecological services: an assessment of the state of the service", Journal of Economic Surveys, 22 (5), 872-908. 